Article

\title{
Experimental Investigation of Chlorella vulgaris and Enterobacter sp. MN17 for Decolorization and Removal of Heavy Metals from Textile Wastewater
}

\author{
Muhammad Mubashar ${ }^{1,2,3}$, Muhammad Naveed ${ }^{3, *(1)}$, Adnan Mustafa ${ }^{4}(\mathbb{D}$, \\ Sobia Ashraf ${ }^{3}$, Khurram Shehzad Baig ${ }^{5}$, Saud Alamri ${ }^{6}$, Manzer H. Siddiqui ${ }^{6}\left({ }^{\circ}\right.$, \\ Magdalena Zabochnicka-Świątek ${ }^{7, *(1)}$, Michał Szota ${ }^{8}$ and Hazem M. Kalaji ${ }^{9}$ \\ 1 Key Laboratory for Algal Biology, Institute of Hydrobiology, Chinese Academy of Sciences, \\ Wuhan 430072, China; mubashar3291@gmail.com \\ 2 Institute of Hydrobiology, University of Chinese Academy of Sciences, Beijing 100049, China \\ 3 Institute of Soil and Environmental Sciences, University of Agriculture, Faisalabad 38040, Pakistan; \\ sobiaashraf13@googlemail.com \\ 4 National Engineering Laboratory for Improving Quality of Arable Land, Institute of Agricultural Resources \\ and Regional Planning, Chinese Academy of Agricultural Sciences, Beijing 100081, China; \\ adnanmustafa780@gmail.com \\ 5 Soil Fertility Institute, Lahore 53700, Punjab, Pakistan; ksb2004@gmail.com \\ 6 Department of Botany and Microbiology, College of Science, King Saud University, Riyadh 11451, \\ Saudi Arabia; saualamri@ksu.edu.sa (S.A.); manzerhs@yahoo.co.in (M.H.S.) \\ 7 Faculty of Infrastructure and Environment, Częstochowa University of Technology, Dabrowskiego 73, \\ 42-201 Częstochowa, Poland \\ 8 Faculty of Processing Engineering and Materials Technology, Częstochowa University of Technology, \\ Armii Krajowej 19, 42-200 Częstochowa, Poland; michal.szota@pcz.pl \\ 9 Department of Plant Physiology, Institute of Biology, Warsaw University of Life Sciences, \\ Nowoursynowska 159, 02-776 Warsaw, Poland; hazem@kalaji.pl \\ * Correspondence: muhammad.naveed@uaf.edu.pk (M.N.); magdalena.zabochnicka@pcz.pl (M.Z.-Ś.); \\ Tel.: +48-343-721-303 (M.Z.-Ś.)
}

Received: 30 July 2020; Accepted: 26 October 2020; Published: 29 October 2020

\begin{abstract}
The present study evaluated the performance of microalgae Chlorella vulgaris in an Enterobacter sp. MN17-assisted textile industry wastewater treatment system for decolorization, removal of heavy metals ( $\mathrm{Cu}, \mathrm{Cr}, \mathrm{Pb}$, and $\mathrm{Cd}$ ), and chemical oxygen demand (COD). Different dilutions $(5,10$, and $20 \%)$ of wastewater were prepared to decrease the pollutant toxicity for culturing microalgae and bacteria. Reduction of color, COD, and metal contents by microalgal treatment of wastewater varied greatly, while removal efficiency (RE) was significantly enhanced when endophytic bacterial strain MN17 inoculum was applied. Most notable, results were found at a 5\% dilution level by Enterobacter sp. MN17-inoculated C. vulgaris medium, as chromium (Cr), cadmium (Cd), copper $(\mathrm{Cu})$, and lead $(\mathrm{Pb})$ concentrations were decreased from 1.32 to $0.27 \mathrm{mg} \mathrm{L}^{-1}$ (79\% decrease), $0.79-0.14 \mathrm{mg} \mathrm{L}^{-1}$ (93\% decrease), $1.33-0.36 \mathrm{mg} \mathrm{L}^{-1}$ (72\% decrease), and $1.2-0.25 \mathrm{mg} \mathrm{L}^{-1}$ (79\% decrease), respectively. The values of COD and color were also significantly decreased by $74 \%$ and $70 \%$, respectively, by a C. vulgaris-Enterobacter sp. MN17 consortium. The present investigation revealed that bacterial inoculation of microalgae significantly enhanced the removal of coloring agents and heavy metals from textile wastewater by stimulating the growth of algal biomass. This study manifested the usefulness of microalgae-bacterial mutualism for the remediation of heavy metals, COD, and color in industrial effluents. Microalgae consortia with growth promoting bacteria could be a breakthrough for better bioremediation and bioprocess economy. Thus, further studies are needed for successful integration of microalgae-plant growth promoting bacterial (PGPB) consortium for wastewater treatments.
\end{abstract}


Keywords: textile effluents; wastewater treatment; algal-bacterial consortium; Chlorella vulgaris; Enterobacter sp. MN17

\section{Introduction}

The textile industry is the most important sector in Pakistan's economy, contributing about 9\% to gross domestic product (GDP), but its impact on the environment is getting worse day by day. Recently, it has become a common practice to discharge wastewater originating from various production processes of textile and dying industrial units directly into water channels. This indiscriminate discharge of industrial effluents is posing serious threats to human and animal health [1]. The textile sector contains many units like dyeing, bleaching, printing, etc., using large quantities of water. About $3840 \mathrm{~m}^{3} /$ day of water is used in these processes of the textile industry [2]. These activities are held responsible for environmental water pollution due to the use of huge amounts of water throughout all the processing operations and release about 35 billion tons of wastewater with high values of $\mathrm{pH}$, electrical conductivity (EC), and total suspended solids (TSS) [3]. More than 70 types of chemicals are present in textile effluents including 30 chemical types that are unable to be removed [4]. Textile wastewater effluents contain substantial amounts of heavy metals, high biological oxygen demand (BOD), and chemical oxygen demand (COD). Therefore, it is highly indispensable to adopt environmentally-friendly methods for the treatment of textile effluents prior to their discharge into natural water bodies, particularly in heavily industrial cities [5].

Wastewater has been characterized with high BOD, COD [6], volatile acids, proteins, lipids, inorganic compounds, i.e., potassium, calcium, chlorine, and heavy metals [7]. Water conservation and reuse have become of the utmost necessity of the textile industry due to the increasing demand of water by both industrial and residential sectors and hence water resource depletion and health risks associated with contaminated water [8].

Treatment of wastewater prior to its discharge into natural water bodies is in dire need currently, owing to its highly hazardous effects on the ecosystem and human health. Application of various physical and chemical technologies requiring high cost and energy for operation and maintenance is not feasible in poor countries like Pakistan [9]. Therefore, biological means of pollutant removal provide cost effective alternative strategies, using biological agents such as algae, fungi, bacteria, etc., and crop residues for the removal of pollutants from wastewater in an efficient, eco-friendly, and sustainable way [10]. Algae sequester atmospheric $\mathrm{CO}_{2}$ with the assimilation of nutrients from wastewater [11]. Algal biomass production can be increased by synergism with suitable bacterial species [12]. Microalgae provide organic compounds and oxygen to the bacteria that are released as algogenic organic matter (AOM) during photosynthesis [13]. Alternatively, bacteria provide $\mathrm{CO}_{2}$ and other growth promoting elements to microalgae, thus acting as growth enhancers for microalgae [13]. Under extreme environmental conditions, bacteria may help algae in buffering the stresses against evapotranspiration and photoinhibition, whereas microalgae in turn provide nitrogen $(\mathrm{N})$ and minerals by the process of mineralization [14]. This microalgal-bacterial symbiosis may produce anti-oxidants that also help them be sustained under extreme conditions [14].

The addition of bacteria in algal culture medium not only enhances algal growth but also its photosynthetic potential by supplying additional $\mathrm{CO}_{2}$ and organic compounds [15]. Algal-bacterial synergistic interaction helps to enhance phosphorus $(\mathrm{P})$ and $\mathrm{N}$ assimilation, which can be recycled by using algae as a fertilizer [16].

Previous work has specifically focused on algal application for wastewater treatments $[17,18]$. However, little is known about algal-endophytic bacterial interactions for treating ind ustrial wastewater. Interestingly, the role of Enterobacter sp. MN17 in treating and decolorization textile wastewater has not yet been explored. Therefore, the present research was designed to investigate the potential of 
microalgae C. vulgaris co-applied with Enterobacter sp. MN17 to remove heavy metals and color from textile wastewater.

\section{Materials and Methods}

\subsection{Culturing Microalgae and Bacterial Strains}

Freshwater green microalgae strain C. vulgaris was kindly donated by Punjab Bioenergy Institute, University of Agriculture, Faisalabad, and bacterial strain Enterobacter sp. MN17 was obtained from the Environmental Sciences Laboratory, University of Agriculture, Faisalabad, Pakistan. Microalgae was pre-cultured in BG-11 media containing $1.5 \mathrm{~g} \mathrm{~L}^{-1} \mathrm{NaNO}_{3}, 0.12 \mathrm{~g} \mathrm{~L}^{-1} \mathrm{~K}_{2} \mathrm{HPO}_{4}, 0.287 \mathrm{~g} \mathrm{~L}^{-1} \mathrm{ZnSO}_{4} \cdot 7 \mathrm{H}_{2} \mathrm{O}_{\text {, }}$ $0.075 \mathrm{~g} \mathrm{~L}^{-1} \mathrm{MgSO}_{4} \cdot 7 \mathrm{H}_{2} \mathrm{O}, 0.036 \mathrm{~g} \mathrm{~L}^{-1} \mathrm{CaCl}_{2} \cdot 2 \mathrm{H}_{2} \mathrm{O}, 0.02 \mathrm{~g} \mathrm{~L}^{-1} \mathrm{Na}_{2} \mathrm{CO}_{3}, 0.169 \mathrm{~g} \mathrm{~L}^{-1} \mathrm{MnSO}_{2} \cdot 2 \mathrm{H}_{2} \mathrm{O}_{\text {, }}$ $0.0006 \mathrm{~g} \mathrm{~L}^{-1}$ Ferric ammonium citrate, $0.001 \mathrm{~g} \mathrm{~L}^{-1}$ EDTA (disodium salt), $0.061 \mathrm{~g} \mathrm{~L}^{-1} \mathrm{H}_{3} \mathrm{BO}_{3}, 0.012 \mathrm{~g} \mathrm{~L}^{-1}$ $\mathrm{NaMoO}_{4} \cdot 2 \mathrm{H}_{2} \mathrm{O}, 0.0025 \mathrm{~g} \mathrm{~L}^{-1} \mathrm{CuSO}_{4} \cdot 5 \mathrm{H}_{2} \mathrm{O}, 0.049 \mathrm{~g} \mathrm{~L}^{-1} \mathrm{Co}\left(\mathrm{NO}_{3}\right)_{2} \cdot 6 \mathrm{H}_{2} \mathrm{O}$, and $0.001 \mathrm{~g} \mathrm{~L}^{-1} \mathrm{MnCl}_{2} \cdot 4 \mathrm{H}_{2} \mathrm{O}$. Bacterium was cultured in tryptic soy broth (TSB) media (Merck, Germany) with pre-sterilization in an autoclave for $20 \mathrm{~min}$ at $121^{\circ} \mathrm{C}$ before its use for microalgae and bacteria cultivation [19]. For seed propagation, Chlorella vulgaris was first cultured in flasks in a growth chamber at light intensity of $60-80 \mu \mathrm{mol} \mathrm{m} \mathrm{m}^{-2} \mathrm{~s}^{-1}$ and temperature of $28 \pm 2{ }^{\circ} \mathrm{C}$ followed by culturing in $5 \mathrm{~L}$ laboratory grade plastic tubes for 7 days. The culture was then used as seed for microalgae growth on textile wastewater. The bacterial culture was prepared in $500 \mathrm{~mL}$ Erlenmeyer flasks in a shaking incubator (Firstek Scientific, Tokyo, Japan) at $150 \mathrm{rpm}$ for $48 \mathrm{~h}$ at $25 \pm 2{ }^{\circ} \mathrm{C}$.

Chlorella vulgaris is widely used for the treatment of wastewater $[20,21]$ and has been proved to efficiently assimilate nutrients from wastewater. The bacterial strain Enterobacter sp. MN17 was selected on the basis of its growth promoting characteristics [22-24] and involvement in improving photosynthetic activity.

Textile industry wastewater was used as a culture medium for microalgae growth, collected from the dying unit of Masood Textile Mill (MTM), Faisalabad and stored at $4{ }^{\circ} \mathrm{C}$ prior to its use. Wastewater was filtered and analyzed for various physico-chemical parameters such as COD, color, and concentration of heavy metals, including chromium $(\mathrm{Cr})$, cadmium $(\mathrm{Cd})$, copper $(\mathrm{Cu})$, and lead $(\mathrm{Pb})$.

\subsection{Algal Growth Determination}

The effect of the growth promoting bacterium Enterobacter sp. MN17 on algal biomass production was evaluated by examining the growth response of pure algal culture and the algal-bacterial consortium for a period of 5 days, and the growth was expressed in terms of biomass concentration. For comparing the growth rate, $C$. vulgaris and the $C$. vulgaris-Enterobacter sp. MN17 consortium were cultured in BG-11 in 1 L flasks with working volumes of $800 \mathrm{~mL}$ having a 0.2 optical density (OD) in a growth chamber at $25 \pm 1{ }^{\circ} \mathrm{C}$ and $24 \mathrm{~h}$ light at $100-120 \mu \mathrm{mol} / \mathrm{m}^{2} / \mathrm{s}$ intensity along with $2 \% \mathrm{CO}_{2}$ mixed with air. All treatments were performed in triplicate, and algal biomass was measured after every $24 \mathrm{~h}$ period using the gravity method.

\subsection{Experimental Setup and Culture Conditions}

For removal of pollutants from textile wastewater, the microalgae strain C. vulgaris was applied with bacterial strain Enterobacter sp. MN17 under different wastewater concentrations. The experiment was performed in $5 \mathrm{~L}$ laboratory grade plastic tubes in a growth chamber. Three different dilutions $(5 \%, 10 \%$, and $20 \%)$ of wastewater were prepared by distilled water to reduce its toxicity. For assessment of the wastewater treatment potential of microalgae with respect to controls of the same dilutions, the $\mathrm{pH}$ of all the dilutions was adjusted to 7.0 before inoculation of algal-bacterial strains. The wastewater dilutions were sterilized after filtering through sterile $0.22 \mu \mathrm{m}$ pore-size filters (ShangHai XinYa Purification Equipment Co., Ltd., Shanghai, China). The microalgal strain C. vulgaris was grown in all these dilutions of wastewater for biomass production. Pre-cultured microalgae were centrifuged at $3700 \times g$ at $20^{\circ} \mathrm{C}$ for $5 \mathrm{~min}$. After the supernatant was discarded, the microalgal cells were washed 
twice with sterile distilled water, and an OD of 0.2 was set using a spectrophotometer (Hach, Loveland, CO, USA) at $750 \mathrm{~nm}$ absorbance. Indoor culture conditions were maintained in a growth chamber with a temperature of $25 \pm 1{ }^{\circ} \mathrm{C}$ and $14: 10 \mathrm{~h}$ light:dark cycle at intensity of $100-120 \mu \mathrm{mol} \mathrm{m}^{-2} \mathrm{~s}^{-1}$ provided with cool white fluorescent lamps. Agitation in culturing flasks was maintained by using air mixed with $2 \% \mathrm{CO}_{2}$.

After culturing, Enterobacter sp. MN17 was placed in a shaking incubator (Firstek Scientific, Tokyo, Japan) at $150 \mathrm{rpm}$ for $48 \mathrm{~h}$ at $25 \pm 2{ }^{\circ} \mathrm{C}$, and the culture was centrifuged (3020× $\mathrm{g}$ rpm for $3 \mathrm{~min}$ ) followed by washing with sterile distilled water. The initial concentrations of MN17 was determined as $2.3 \times 10^{5}$ cells $\mathrm{mL}^{-1}$, whereas the inoculum ratio of Chlorella to Enterobacter was 5:1, which was selected based on the preliminary testing of the effective consortium ratio. The higher Chlorella to Enterobacter ratio was selected based on the fact that a bacterial population does not result in an uncontrolled culture, and a good productivity and removal of heavy metals should be maintained under a higher microalgae population.

\subsection{Analytical Procedures}

Chemical oxygen demand was determined by following the method described by [25]. The samples were oxidized by potassium dichromate $\left(\mathrm{K}_{2} \mathrm{Cr}_{2} \mathrm{O}_{7}\right)$ in sulfuric acid. Silver sulfate $\left(\mathrm{AgSO}_{4}\right)$ and mercuric sulfate $\left(\mathrm{HgSO}_{4}\right)$ were used as catalysts. The excess dichromate concentration was measured by titration with ferrous ammonium sulfate. Decolorization was measured by using the difference between spectrophotometer absorbance readings before and after the experiment. The maximum absorbance wavelength $\left(\lambda_{\max }\right)$ was determined using a spectrophotometer (Hach, Loveland, CO, USA) at wavelengths ranging between 250 and $700 \mathrm{~nm}$ of the wastewater sample. After microalgae culturing in selected dilutions, the cells were harvested by centrifugation at $3500 \mathrm{rpm}$ for $5 \mathrm{~min}$. The supernatant was collected and again subjected to absorption spectrums till the disappearance of the absorbance peaks at $\lambda_{\max }$. Percentage color removal was calculated as follows:

$$
\% \text { decolorization }=\left(\text { Initial } \lambda_{\max }-\text { final } \lambda_{\max } / \text { initial } \lambda_{\max }\right) \times 100 \%
$$

The amount of heavy metals in the prepared wastewater samples was determined by using an atomic absorption spectrophotometer (AAS) (Hitachi Polarized Zeeman AAS, Z-8200, Japan), following the conditions described by $[25,26]$. The metal removal efficiency (RE) was calculated using the following equation:

$$
\text { Removal efficiency }(\mathrm{RE} \%)=x i-x f / x i \times 100
$$

where $\mathrm{xi}$ is the parameter value before the experiment, and $\mathrm{xf}$ is the parameter value after the experiment. For dry weight, cells were harvested by filtration (Whatman GF/C) after drying the pre-weighed filter at $105^{\circ} \mathrm{C}$ in an oven for $24 \mathrm{~h}$ followed by cooling in a desiccator for $30 \mathrm{~min}$; dry weight was determined by using the following formula:

$$
\text { Dry weight }(\mathrm{g} / \mathrm{L})=\frac{(\text { Weight of filter with algal sample }- \text { weight of filter before })}{\text { volume of sample }} \times 1000
$$

\subsection{Statistical Data Analysis}

Statistical analysis was carried out using SPSS 16.0 (Chicago, IL, USA) for windows. A completely randomized design (CRD) factorial test followed by least significant difference (LSD) was used to analyze data and to check the significance of treatments at a 5\% level of significance. Data were presented as mean \pm standard deviation unless otherwise stated. All the graphs were prepared on Microsoft Excel 365 version. 


\section{Results}

\subsection{Growth Comparison of C. vulgaris vs. C. vulgaris-Enterobacter sp. Mn17 Consortium}

The growth of $C$. vulgaris reached its maximum level after day 4 and then levelled off, whereas for the consortium, the $C$. vulgaris response was much better even after $96 \mathrm{~h}$. Maximum biomass was achieved with bacterial inoculated culture of $2.97 \mathrm{~g} \mathrm{~L}^{-1}$ with a maximum biomass productivity of $0.902 \mathrm{~g} \mathrm{~L}^{-1} \mathrm{day}^{-1}$, which was much higher than the individual algal culture, with a maximum biomass of $2.18 \mathrm{~g} \mathrm{~L}^{-1}$ and a maximum biomass productivity of $0.67 \mathrm{~g} \mathrm{~L}^{-1} \mathrm{day}^{-1}$. Growth on the first day was the same for both cases but on the second day showed the highest difference, which might be the result of more $\mathrm{CO}_{2}$ incorporation to the biomass, which further increased nutrient uptake (Figure 1).

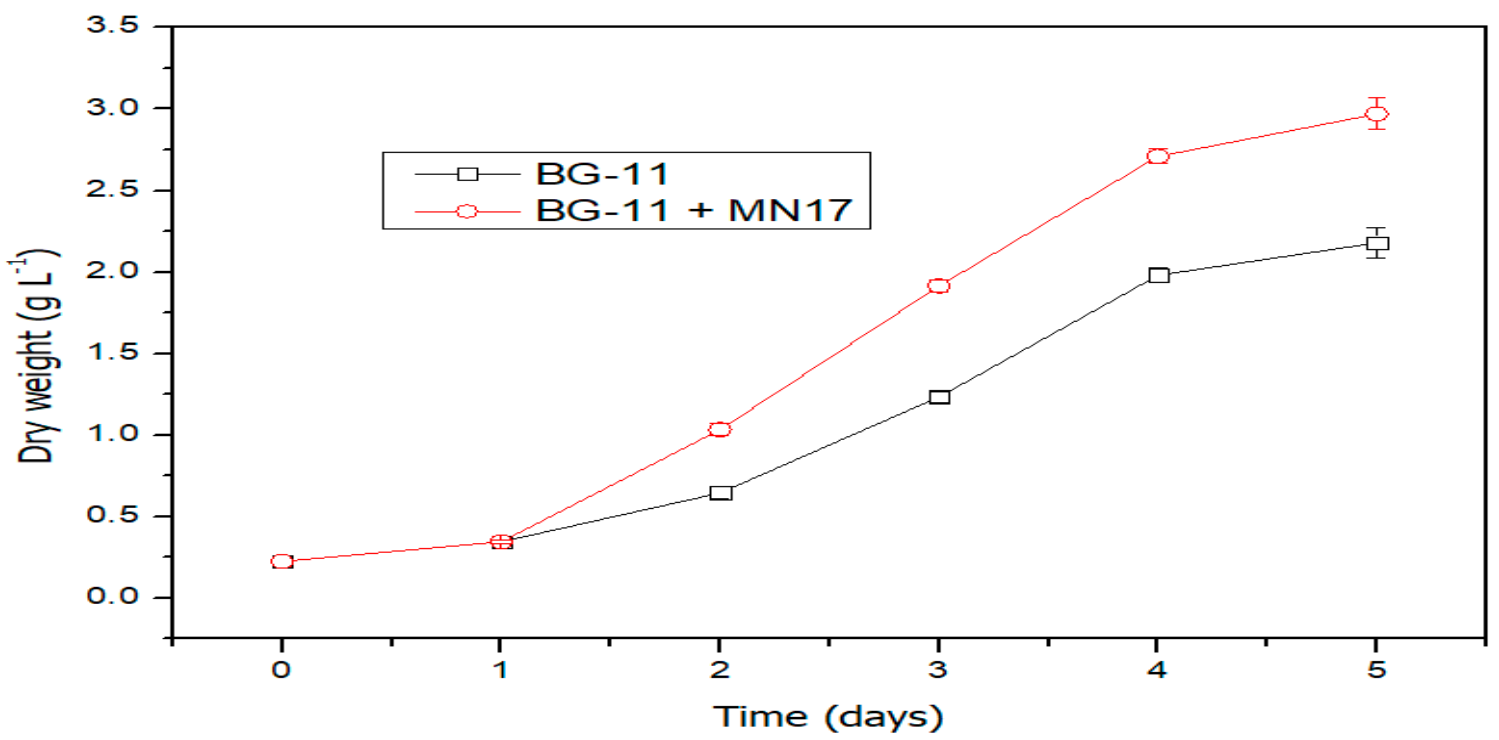

Figure 1. Biomass changes of Chlorella vulgaris and C. vulgaris-Enterobacter sp. MN17 consortium in BG-11 media.

\subsection{Effects of Algal-Bacterial Consortium on Wastewater Treatment}

\subsubsection{Decolorization Assay}

The effect of $C$. vulgaris individually and in combination with Enterobacter sp. MN17 on decolorization of three diluted concentrations of textile dyeing unit wastewater is shown in (Figure 2). The coloring was removed from all the dilutions to varying extents. The efficiency of C. vulgaris in decolorization was $43 \%, 37 \%$, and $29 \%$ at wastewater dilutions of 5,10 , and $20 \%$, respectively. However, decolorization with application of C. vulgaris in combination with Enterobacter sp. MN17 was much better as compared to the individual application of $C$. vulgaris, as decolorization RE was increased up to $71.5 \%, 56 \%$, and $49 \%$ in all $(5,10$, and $20 \%)$ dilutions, respectively, which was much better than with only microalgae. An increase in microalgal biomass was observed with Enterobacter sp. MN17 application, which resulted in more decolorization. Color removal by C. vulgaris decreased with the increase in initial color, especially in medium containing $20 \%$ wastewater, whereas bacteria assisted microalgae to perform better in more toxic environments. Maximum decolorization was recorded at 5\% dilution while inoculation of bacteria had significant effect on decolorization (Figure 2). In general, Enterobacter sp. MN17 improved the growth of C. vulgaris in all dilutions that resulted in enhanced decolorization. 


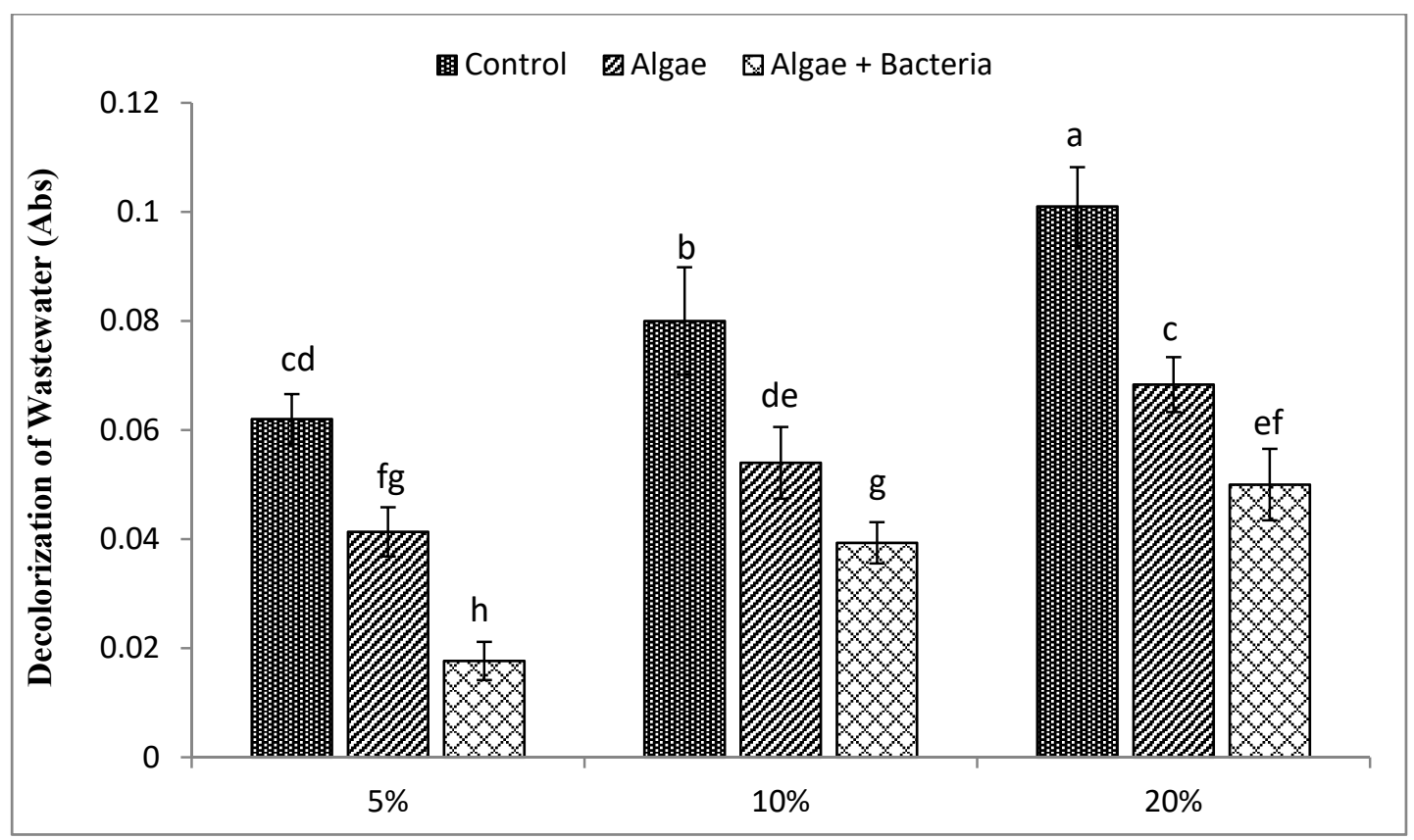

Figure 2. Efficiency of algae and algal-bacterial consortium for decolorization of textile industry wastewater with respect to their control values at different dilution levels. Columns show mean values and bars show standard deviation (SD) of means. All means followed by different letters were significantly different according to Tukey HSD (honestly significant difference) test at $p<0.05$.

\subsubsection{Removal of Heavy Metals}

The dying unit wastewater contained various heavy metals of which $\mathrm{Cr}, \mathrm{Cd}, \mathrm{Cu}$, and $\mathrm{Pb}$ were found above the permissible limits, whereas others were below the acceptable limits, which is why they were ignored in this study. In the present study, $\mathrm{Cr}, \mathrm{Cd}, \mathrm{Cu}$, and $\mathrm{Pb}$ concentration ranges were $1.32-2.02 \mathrm{mg} \mathrm{L}^{-1}, 0.79-1.08 \mathrm{mg} \mathrm{L}^{-1}, 1.33-1.88 \mathrm{mg} \mathrm{L}^{-1}$, and $1.21-1.58 \mathrm{mg} \mathrm{L}^{-1}$, respectively, in all wastewater dilutions. The concentrations of these heavy metals in different dilutions are presented in (Table 1).

Table 1. Pollutant removal efficiencies of microalgae and microalgal-bacterial consortium from textile industry wastewater at different dilution levels.

\begin{tabular}{|c|c|c|c|c|}
\hline \multirow{2}{*}{ Parameters } & \multirow{2}{*}{ Dilution Level } & \multirow{2}{*}{ Control $\mathrm{mg} \mathrm{L}^{-1}$} & \multicolumn{2}{|c|}{ Removal Efficiency (\%) } \\
\hline & & & Algae & Algae + Bacteria \\
\hline \multirow{3}{*}{ Chromium (Cr) } & $5 \%$ & 1.32 & 58 & 79 \\
\hline & $10 \%$ & 1.79 & 56 & 71 \\
\hline & $20 \%$ & 2.02 & 44 & 62 \\
\hline \multirow{3}{*}{ Cadmium (Cd) } & $5 \%$ & 0.79 & 59 & 93 \\
\hline & $10 \%$ & 0.91 & 25 & 53 \\
\hline & $20 \%$ & 1.08 & 36 & 37 \\
\hline \multirow{3}{*}{ Copper $(\mathrm{Cu})$} & $5 \%$ & 1.33 & 45 & 72 \\
\hline & $10 \%$ & 1.49 & 32 & 62 \\
\hline & $20 \%$ & 1.88 & 32 & 60 \\
\hline \multirow{3}{*}{ Lead $(\mathrm{Pb})$} & $5 \%$ & 1.21 & 61 & 79 \\
\hline & $10 \%$ & 1.41 & 53 & 70 \\
\hline & $20 \%$ & 1.58 & 39 & 63 \\
\hline \multirow{3}{*}{$\begin{array}{l}\text { Chemical oxygen } \\
\text { demand (COD) }\end{array}$} & $5 \%$ & 755 & 19 & 74 \\
\hline & $10 \%$ & 820 & 41 & 53 \\
\hline & $20 \%$ & 871 & 30 & 38 \\
\hline
\end{tabular}


The removal of $\mathrm{Cr}, \mathrm{Cd}, \mathrm{Cu}$, and $\mathrm{Pb}$ by $\mathrm{C}$. vulgaris was individually compared to the consortium of $C$. vulgaris and Enterobacter sp. MN17 from initial concentrations with their removal efficiencies in (Table 1). The highest concentrations were found for $\mathrm{Cu}$ followed by $\mathrm{Cr}, \mathrm{Pb}$, and $\mathrm{Cd}$ in all three dilutions. Removal efficiency of $\mathrm{Cr}$ (Figure 3) was $58 \%, 56 \%$, and $44 \%$, respectively, by algae, while RE by the algal-bacterial consortium for $\mathrm{Cr}$ was $79 \%, 71 \%$, and $62 \%$ at $5 \%, 10 \%$, and $20 \%$ dilutions, respectively. Algae removed $\mathrm{Cd}$ at all dilutions. Cd (Figure 4) removal by algae at $5 \%$ dilution ranged from $0.79 \mathrm{mg}$ $\mathrm{L}^{-1}$ to $0.32 \mathrm{mg} \mathrm{L}^{-1}$ (RE 59\%), at $10 \%$ dilution Cd decreased from $0.91 \mathrm{mg} \mathrm{L}^{-1}$ to $0.68 \mathrm{mg} \mathrm{L}^{-1}$ (RE $25 \%$ ), and at $20 \%$ dilution level $\mathrm{Cd}$ decreased from $1.08 \mathrm{mg} \mathrm{L}^{-1}$ to $0.69 \mathrm{mg} \mathrm{L}^{-1}$ (RE $36 \%$ ). The algal-bacterial consortium showed better results for Cd treatment with an RE of $93 \%, 53 \%$, and $36 \%$ at $5 \%, 10 \%$, and $20 \%$ dilutions, respectively, over other studied metals.

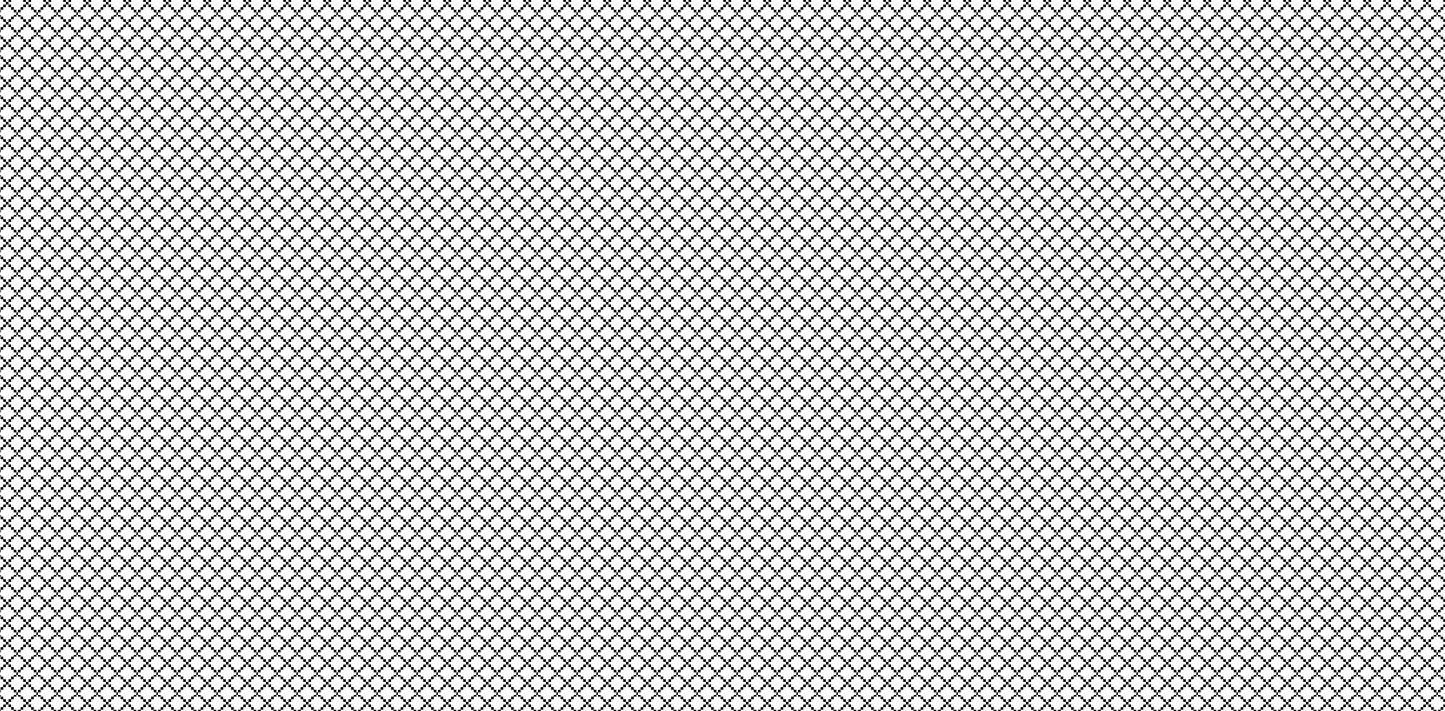

Figure 3. Efficiency of algae and algal-bacterial consortium for chromium removal from textile industry wastewater. Column shows mean values, and bars shows standard deviations (SD) of means. All means followed by different letters were significantly different according to Tukey HSD test at $p<0.05$.

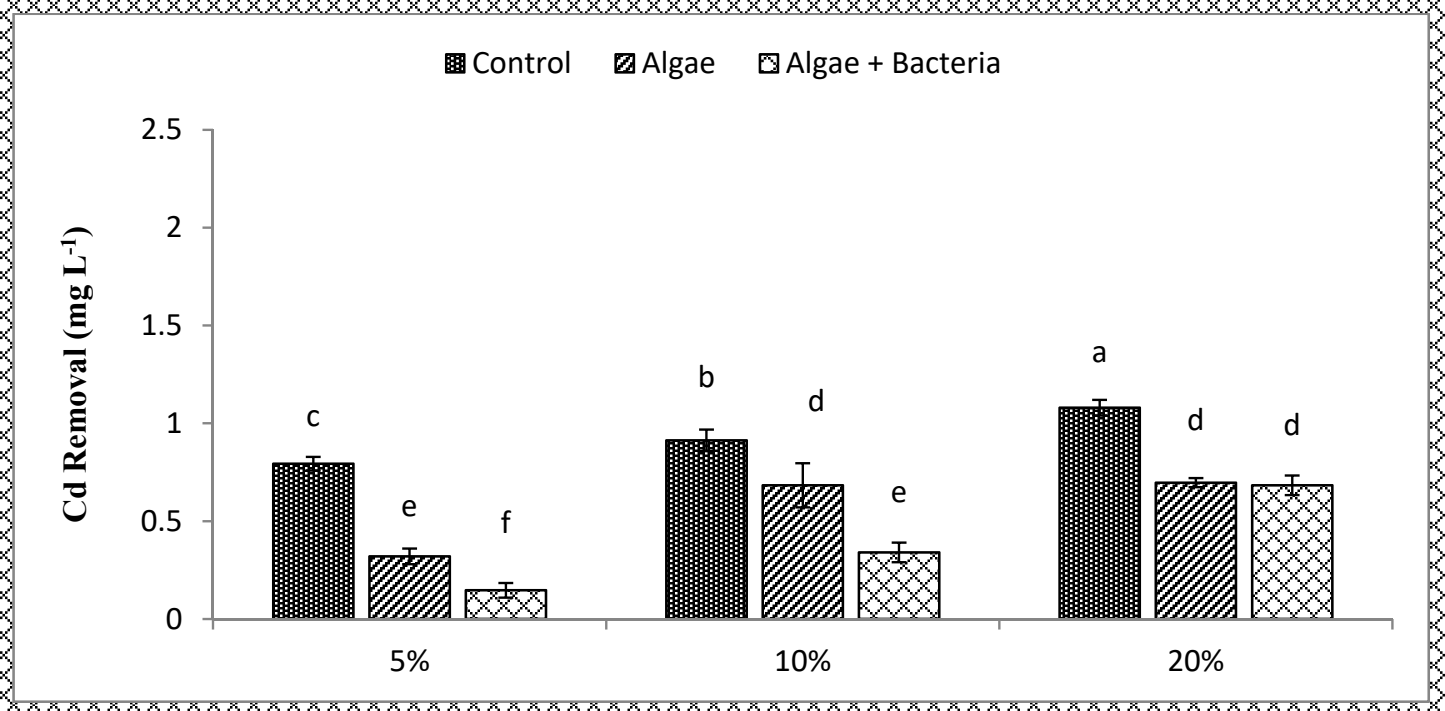

Figure 4. Efficiency of algae and algal-bacterial consortium for cadmium removal from textile industry wastewater at different dilution levels. Column shows mean values, and bars shows standard deviation (SD) of means. All means followed by different letters were significantly different according to Tukey HSD test at $p<0.05$. 
By the end of the experiment, residual quantities of $\mathrm{Cr}, \mathrm{Cd}, \mathrm{Cu}$, and $\mathrm{Pb}$ were still detected, reaching concentrations of $0.56,0.32,0.73$, and $0.47 \mathrm{mg} \mathrm{L}^{-1}$, with algae, whereas they reached concentrations of $0.27,0.14,0.37$, and $0.25 \mathrm{mg} \mathrm{L}^{-1}$ with the microalgal-bacterial consortium, respectively, at $5 \%$ dilution level. Results indicated that the lowest RE at 5\% dilution was achieved for $\mathrm{Cu}(45 \%)$ (Figure 5) and the highest for $\mathrm{Pb}(61 \%)$ (Figure 6) by algae, while the algal-bacterial consortium showed the highest $\mathrm{RE}$ for $\mathrm{Cd}(93 \%)$ (Figure 4$)$ and the lowest for $\mathrm{Cu}(72 \%)$ at $5 \%$ dilution. At all dilution levels, heavy metal removal improved with bacterial inoculation due to higher growth of C. vulgaris, except for Cd (37\%) at $20 \%$ dilution, which is contradictory to results for other metals from the same study, which might be due to the decreased uptake efficiency of $C$. vulgaris.

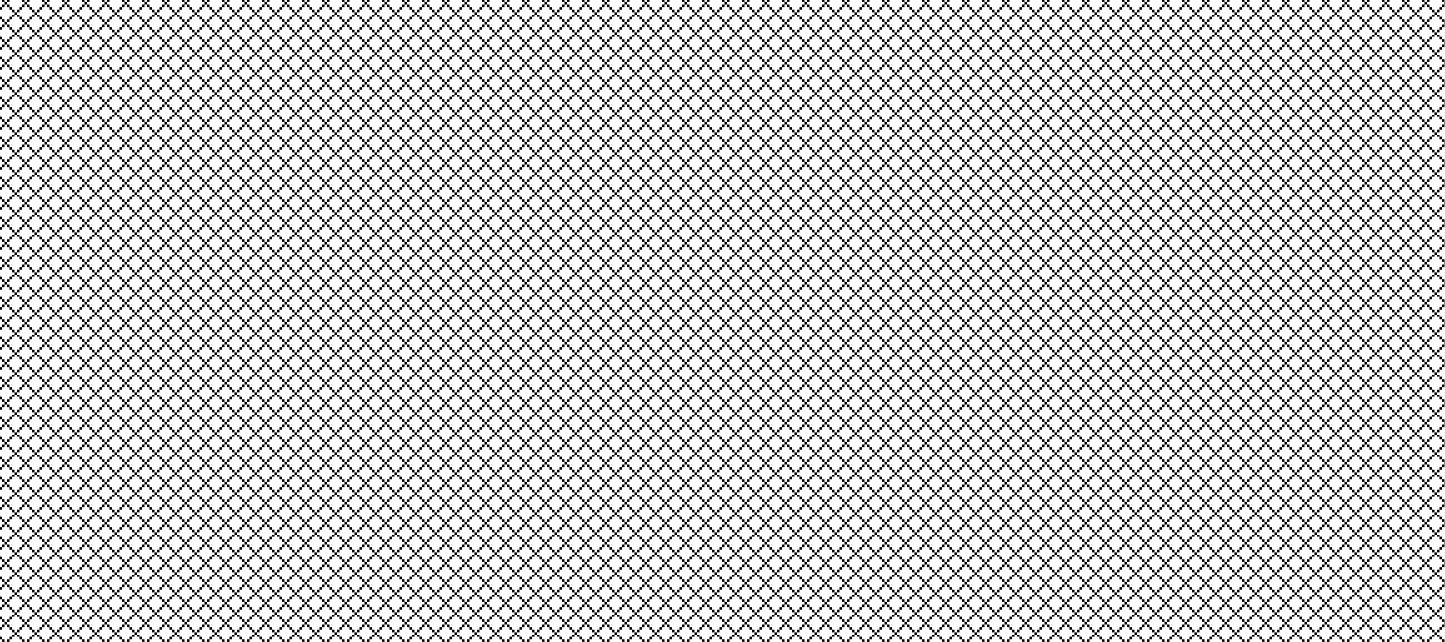

Figure 5. Efficiency of algae and algal-bacterial consortium for copper removal from textile industry wastewater at different dilution levels. Columns show mean values, and bars show standard deviation (SD) of means. All means followed by different letters were significantly different according to Tukey HSD test at $p<0.05$.

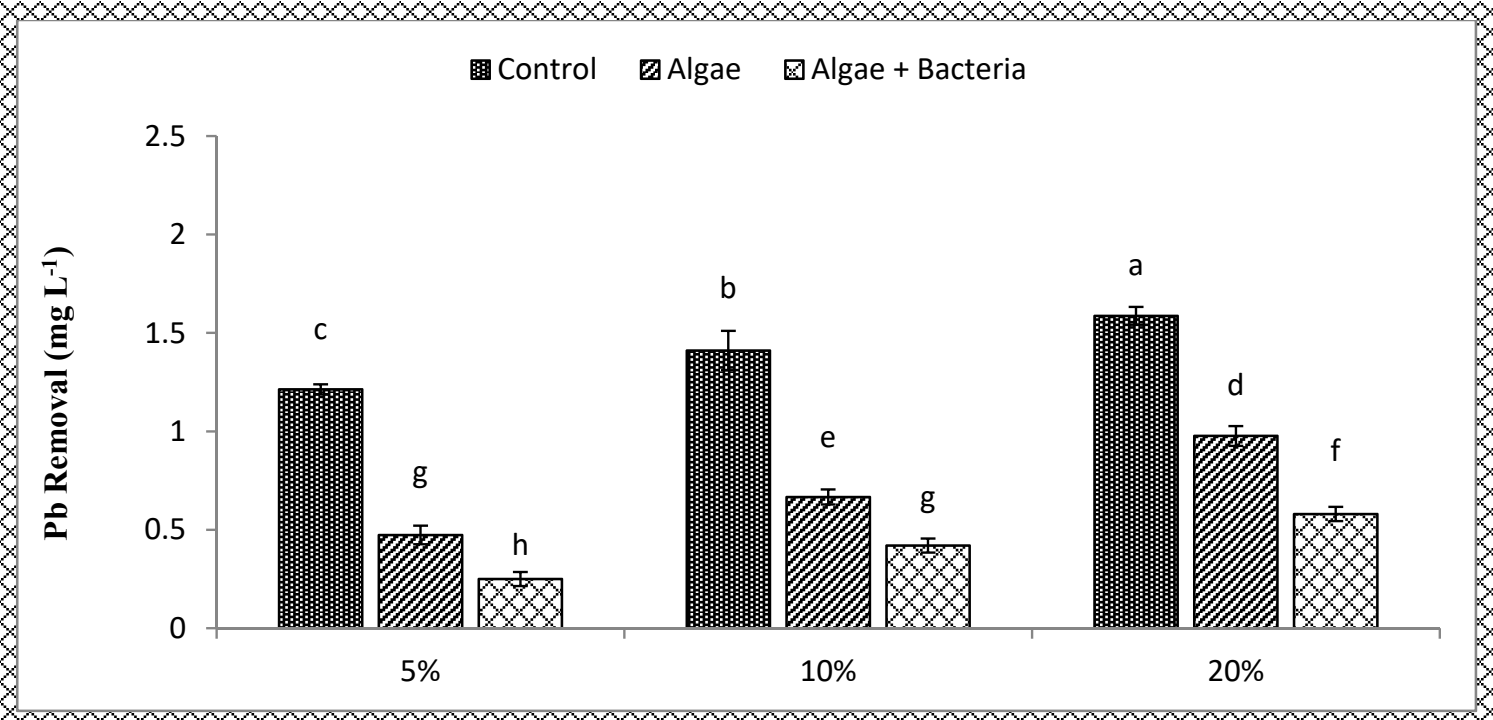

Figure 6. Efficiency of algae and algal-bacterial consortium for lead removal from textile industry wastewater at different dilution levels. Column shows mean values, and bars shows standard deviation (SD) of means. All means followed by different letters were significantly different according to Tukey HSD test at $p<0.05$.

Removal efficiencies of $C$. vulgaris and the $C$. vulgaris-Enterobacter sp. MN17 consortium for COD in textile wastewater treatment are given in (Table 1). Removal efficiency of $C$. vulgaris at $5 \%, 10 \%$, 
and $20 \%$ dilutions were $49 \%, 41 \%$, and $30 \%$, respectively, for COD. The concentration of COD in the control was 755,820 , and $871 \mathrm{mg} \mathrm{L}^{-1}$ at $5 \%, 10 \%$, and $20 \%$ dilutions, respectively, which decreased to 395,486 , and $601 \mathrm{mg} \mathrm{L}^{-1}$ by C. vulgaris, and to 200,387 , and $545 \mathrm{mg} \mathrm{L}^{-1}$ by the C. vulgaris and Enterobacter sp. MN17 consortium in the corresponding dilution levels, respectively. The highest removal efficiencies of $49 \%$ and $74 \%$ were achieved by C. vulgaris and the consortium, respectively, at $5 \%$ dilution level in both treatments. Thus, the results revealed that the algal-bacterial consortium had comparatively high COD removal efficiency as compared to algae.

\section{Discussion}

Application of growth promoting bacteria for enhancing plant growth has recently achieved much attention under normal as well as stressed environments [27-30], but utilization of these bacteria for algae culturing was scarcely evaluated, especially for wastewater treatment. Here, we evaluated the potential of Enterobacter sp. MN17, a potential growth promoting bacterium, for enhancing algal growth in a textile wastewater treatment system. Bacteria can assist microalgae in multiple ways to improve productivity or decrease toxicity of a medium. Microalgae in symbiotic association with bacteria may help deoxygenate the culture media and avoid oxyinhibition. Alternatively, microalgae may serve as a habitat for bacteria for protection from severe environmental conditions [15]. Bacteria also decrease the time to half, required by algae for wastewater treatment, to achieve standard limits of wastewater [31].

We found $0.8 \mathrm{~g} \mathrm{~L}^{-1}$ more biomass by application of Enterobacter sp. MN17 to C. vulgaris culture. Maximum biomass productivity of $0.902 \mathrm{~g} \mathrm{~L}^{-1}$ day $^{-1}$ was achieved with Enterobacter sp. MN17, which is also higher compared to only C. vulgaris for the same period. In the C. vulgaris-Enterobacter consortium, $\mathrm{NO}_{3}{ }^{-}$concentration on the fourth day of cultivation was only $56 \mathrm{mg} \mathrm{L}^{-1}$, which might be the reason for decreased growth after the fourth day, which at the end of the fifth day further decreased to $21 \mathrm{mg} \mathrm{L}^{-1}$. The authors in [32] cultured C. vulgaris with Bacillus pumilus and reported enhanced growth of $C$. vulgaris after $48 \mathrm{~h}$, which in the MN17 case, started after a $24 \mathrm{~h}$ period, which means MN17 also played a role in shortening the lag phase. The authors in [33] also cultured Azospirillum brasilense, a growth promoting bacteria, with $C$. vulgaris and reported enhanced nutritional capacity of $C$. vulgaris with bacterial association, which aligns with the results of our study.

Coloring agents are main components of textile industry effluents, which are highly hazardous to the environment. Microalgae play a significant role in the decolorization of these effluents in a cost-effective way by the adsorption of dyes on algal cells [34], while other studies reported that color removal from effluents using microalgae involves biosorption [35]. Chlorella sp. has the ability to decolorize the textile wastewater over a certain range of toxicity, but with increases in toxicity, its ability to decolorize dyed water decreases. We found decolorization efficiency of $29-43 \%$ for C. vulgaris and $49-71.5 \%$ for the Chlorella-Enterobacter consortium in corresponding dilutions. These results are in good agreement with [36], who observed that the decolorization is actually linked with active C. vulgaris growth, which supports our results of enhanced decolorization by Enterobacter sp. MN17. The present study also indicated that growth promoting bacterium Enterobacter sp. MN17 assisted C. vulgaris growth in toxic conditions, resulting in enhanced color removal efficiency.

Concentrations of all the studied heavy metal were beyond the permissible limits of $1 \mathrm{mg} \mathrm{L}^{-1} \mathrm{Cr}$,

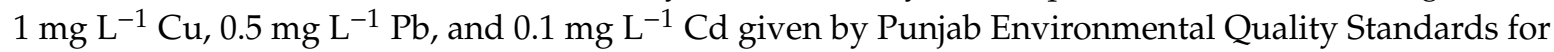
Municipal and Liquid Industrial Effluents (PEQS) [37] and also greater than the reported values from previous studies $[38,39]$. Abnormal growth of $C$. vulgaris occurs if heavy metal concentration increases to a certain range [40], which is why textile wastewater was subjected to different dilutions to decrease the toxicity level for microalgae, and also why Enterobacter sp. MN17 was selected to assist microalgae in coping with the more toxic environment.

Almost all autotrophic microorganisms have the capability to fix heavy metals by a variety of processes such as physical adsorption, chelation, chemisorption, ion exchange, precipitation, and crystallization on the cell surface or extracellular metabolites [11,41]. The removal efficiencies (Table 1) of these metals were affected by their initial concentrations in the present study. Our results 
for initial concentrations were consistent with previous studies [17,42], revealing a direct link between removal efficiency and initial concentration of pollutants. In this study, removal of metals was improved by diluting the textile wastewater to varying extents. At these dilutions, removal efficiency of C. vulgaris varied widely in the ranges of $44-58 \%, 25-59 \%, 32-45 \%$, and $39-61 \%$ for $\mathrm{Cr}, \mathrm{Cd}, \mathrm{Cu}$, and $\mathrm{Pb}$, respectively, whereas in the case of the algal-bacterial consortium, RE varied in the ranges of $62-79 \%$, $37-93 \%, 60-72 \%$, and 63-79\%, respectively. The removal of these metals involves a combination of several processes, including metal species, initial concentration, and bacterial abundance [42].

In the present study, $\mathrm{Cu}$ RE ranged between 32 and $45 \%$ in their corresponding dilutions by C. vulgaris, which is in contrast to studies reporting RE of C. vulgaris as 55\% and Chlorella pyrenoidosa as $80 \%$ [43] and [17]. The initial $\mathrm{Cu}$ concentrations in [43] and [17] were much lower than our three dilution levels. Less removal in our study might be due to the saturation of C. vulgaris. Similar results were reported by authors in [44], who studied the contact time for biosorption of $\mathrm{Cu}$ with Scenedesmus obliquus and reported high initial removal followed by a decrease in performance due to saturation. Cadmium RE at 20\% dilution was very low for both microalgae and the microalgae-bacteria consortium, which might be due to the inability of C. vulgaris to store Cd in its biomass, but still, results in this study are much more satisfactory compared to other studies. The authors in [45] achieved only $24.1 \pm 3.1 \%$ of Cd removal from simulated wastewater using Scenedesmus incrassatulus. Authors in [42] also reported lower $\mathrm{RE}$ for $\mathrm{Cr}, \mathrm{Cd}$, and $\mathrm{Pb}$ by C. vulgaris. Cadmium results of $20 \%$ dilution by both microalgae and consortia align with our study, but for $\mathrm{Cr}$ and $\mathrm{Pb}$, our study results are contradictory to the findings of [42]. A possible reason for higher RE for some metals might be that these metals were used by microalgae for maintenance of their activities and functions [46].

Gupta et al. [47] tested COD RE (\%) of Chlorella sorokiniana and Scenedesmus obliquus from raw sewage wastewater. They achieved $76.13 \pm 1.59 \%$ COD removal by S. obliquus and $69.38 \pm 1.81 \%$ by $C$. sorokiniana, which are much higher than our results found by C. vulgaris but closer to the Chlorella-Enterobacter consortium. The reason for higher RE in [47] might be that the initial COD was only $320.07 \pm 3.78 \mathrm{mg} \mathrm{L}^{-1}$, which is much lower compared to our study. Comparing the RE of S. obliquus and C. sorokiniana with the C. vulgaris-Enterobacter consortium results from our study revealed that the Chlorella-Enterobacter consortium is more efficient for COD removal. Authors in [48] studied the symbiotic relationship of wastewater borne bacteria and C. vulgaris and reported enhanced COD removal. Wastewater borne bacteria break down complex organic compounds into simple molecules, which make nutrients usable for algae, thus removing higher amounts of COD; but Enterobacter is a growth promoting endophytic bacteria, so higher pollutant removal in our study was due to the enhanced growth of C. vulgaris in the presence of Enterobacter sp. MN17.

The concentrations of all heavy metals for microalgae-bacteria treatment after harvesting were much lower than permissible limits of PEQS except for those of $\mathrm{Cd}$, which were in range of only $5 \%$ dilution. Keeping in view these results, wastewater was safe to release to water bodies or to use for irrigation purposes. Although application of bacteria improved heavy metal removal efficiency in diluted samples, culturing microalgae in real textile wastewater still needs a breakthrough in research. For higher degradation and removal of toxic pollutants, attention should be given to developing an effective and efficient consortium where either genetically engineered microalgae or bacteria should be involved for higher efficiencies [31].

For microalgae growth, the dilutions of textile wastewater are limited due to the high cost of clean water, increased volume, artificial nutrients for improving the efficiency, and other inconvenient factors regarding operation and maintenance of the treatment system at a large scale. Therefore, development of an efficient system that allows microalgae to grow well in undiluted textile wastewater is very important. For the same reason, authors in [49] introduced a biofilm-attached culture system for swine wastewater for making the application of microalgae-based technology environmentally and economically feasible for large scale wastewater treatment operations that reduced the pollutant toxicity with improved microalgal growth. Some researchers also proposed mixed microalgae cultures for enhancing nutrient and heavy metal uptake from wastewater and proposed that one microalga can 
remove $\mathrm{N}$, whereas another can remove metals [50-52] from wastewater. Application of bacteria to microalgae-based treatment systems is also a novel approach for reducing the toxicity of wastewater and improving algal growth, but this field still needs much attention to be able to replace chemical-based costly technologies with no or little resource recovery.

\section{Conclusions}

The present investigation revealed considerable growth of the microalgae strain C. vulgaris in different dilution levels of textile wastewater. Addition of bacterial inoculation (Enterobacter sp. MN17) to the treatment system further enhanced the biomass production and remediation potential of C. vulgaris, resulting in the effective removal of color, metals, and other contaminants from wastewater. Removal of COD from wastewater by C. vulgaris was $49 \%$ at $5 \%$ dilution, which increased to $74 \%$ with bacterial inoculation. Similarly, significant removal efficiencies were also achieved for all the studied heavy metals $(\mathrm{Pb}, \mathrm{Cd}, \mathrm{Cr}$, and $\mathrm{Cu})$. The maximum removal achieved was $59 \%$ by microalgae and $93 \%$ by the microalgal-bacterial consortium for $\mathrm{Cd}$ at a $5 \%$ dilution level of wastewater. The resulting algal biomass after wastewater treatment can be profitably converted into bioenergy, thus making this biological process more feasible, reliable, and appealing with the dual benefits of waste reduction and bioenergy production in an economical and environmentally-friendly and sustainable way.

Author Contributions: Conceptualization, M.N. and M.H.S.; methodology, M.M.; software, A.M., K.S.B.; validation, A.M., S.A. (Sobia Ashraf), and M.H.S.; formal analysis, M.M.; investigation, M.N.; resources, M.N.; data curation, M.M.; writing—original draft preparation, M.M.; writing—review and editing, M.N.; visualization, S.A. (Sobia Ashraf); supervision, M.N., M.Z.-Ś., H.M.K. and M.S.; project administration, M.N.; funding acquisition, S.A. (Saud Alamri). All authors have read and agreed to the published version of the manuscript.

Funding: Researchers Supporting Project number (RSP-2020/194), King Saud University, Riyadh, Saudi Arabia. The scientific research was funded by the statute subvention of Czestochowa University of Technology, Faculty of Infrastructure and Environment-BS/PB/400-301/20.

Acknowledgments: The authors would like to extend their sincere appreciation to the Researchers Supporting Project number (RSP-2020/194), King Saud University, Riyadh, Saudi Arabia.

Conflicts of Interest: The authors declare no conflict of interest.

\section{References}

1. Aslam, M.M.; Baig, M.; Hassan, I.; Qazi, I.A.; Malik, M.; Saeed, H. Textile wastewater characterization and reduction of its cod and bod by oxidation. Electron. J. Environ. Agric. Food Chem. 2004, 3, 804-811.

2. Aleem, M.; Nasir, A.; Rashid, H. Characterization and removal of dyeing effluents by adsorption and coagulation methods. J. Agric. Res. 2016, 54, 97-106.

3. Bibi, R.; Ditta, A.; Hussain, A.; Noureen, S.; Khalid, A.; Aziz, I. Production of Algal Biomass Using Different Dilutions of Textile Effluent Wastewater. Sci. Lett. 2016, 4, 71-77.

4. Kant, R. Textile dyeing industry an environmental hazard. Nat. Sci. 2012, 4, 22-26. [CrossRef]

5. Sivakumar, D.; Shankar, D.; Prathima, A.V.; Valarmathi, M. Constructed wetland treatment of textile industry wastewater using aquatic macrophytes. Int. J. Environ. Sci. 2013, 3, 1223.

6. Shaheen, S.R.; Akbar, I.; Malik, W.; Asif, M. Syndicate Report, Textile Sector Is the Backbone of Pakistan's Economy. The Ill Faced by Sector and Its Contribution towards Economic Development; FBR report; Govt. of Pakistan: Islamabad, Pakistan, 2010; pp. 22-23.

7. Abdel-Raouf, N.; Al-Homaidan, A.; Ibraheem, I. Microalgae and wastewater treatment. Saudi J. Biol. Sci. 2012, 19, 257-275. [CrossRef] [PubMed]

8. Huma, H.; Mehmood, Q.; Parvez, A.; Bhatti, Z.A.; Baig, S.A. Comparative decolorizations of dyes in textile wastewater using biological and chemical treatment. Sep. Purif. Technol. 2015, 154, 149-153.

9. Talaie, A.; Beheshti, M.; Talaie, M.R. Screening and batch treatment of wastewater containing floating oil using oil-degrading bacteria. Desalin. Water. Treat. 2011, 28, 108-114. [CrossRef]

10. Kim, S.; Dale, B.E. Allocation procedure in ethanol production system from certain grain system expansion. Int. J. Life Cycle Assess. 2007, 7, 237-243. [CrossRef] 
11. Munoz, R.; Guieysse, B. Algal-bacterial processes for the treatment of hazardous contaminants: A review. Water Res. 2006, 40, 2799-2815. [CrossRef]

12. Mujtaba, G.; Rizwan, M.; Lee, K. Removal of nutrients and COD from wastewater using symbiotic co-culture of bacterium Pseudomonas putida and immobilized microalga Chlorella vulgaris. J. Ind. Eng. Chem. 2017, 49, 145-151. [CrossRef]

13. Bordel, S.; Guieysse, B.; Munoz, R. Mechanistic model for the reclamation of industrial wastewaters using algal- bacterial photobioreactors. Environ. Sci. Technol. 2009, 43, 3200-3207. [CrossRef]

14. Wierzchos, J.; DiRuggiero, J.; Vítek, P.; Artieda, O.; Souza-Egipsy, V.; Skaloud, P.; Tisza, M.; Davila, A.F.; Vílchez, C.; Garbayo, I. Adaptation strategies of endolithic chlorophototrophs to survive the hyper arid and extreme solar radiation environment of the Atacama Desert. Front. Microbiol. 2015, 6, 934. [CrossRef] [PubMed]

15. Unnithan, V.V.; Unc, A.; Smith, G.B. Mini-review: A priori considerations for bacteria-algae interactions in algal biofuel systems receiving municipal wastewaters. Algal Res. 2014, 4, 35-40. [CrossRef]

16. Rawat, I.; Kumar, R.R.; Mutanda, T.; Bux, F. Dual role of microalgae: Phycoremediation of domestic wastewater and biomass production for sustainable biofuels production. Appl. Energy. 2011, 88, 3411-3424. [CrossRef]

17. Zhou, G.J.; Peng, F.Q.; Zhang, L.J.; Ying, G.G. Biosorption of zinc and copper from aqueous solutions by two freshwater green microalgae Chlorella pyrenoidosa and Scenedesmus obliquus. Environ. Sci. Pollut. Res. 2012, 19, 2918-2929. [CrossRef]

18. Molazadeh, P.; Khanjani, N.; Rahimi, M.R.; Nasiri, A. Adsorption of lead by Microalgae Chaetoceros Sp. and Chlorella Sp. from aqueous solution. J. Community Health Res. 2015, 4, 114-127.

19. Naveed, M.; Mitter, B.; Yousaf, S.; Pastar, M.; Afzal, M.; Sessitsch, A. The endophyte Enterobacter sp. FD17: A maize growth enhancer selected based on rigorous testing of plant beneficial traits and colonization characteristics. Biol. Fertil. Soils 2014, 50, 249-262. [CrossRef]

20. Kube, M.; Mohseni, A.; Fan, L.; Roddick, F. Impact of alginate selection for wastewater treatment by immobilized Chlorella vulgaris. Chem. Eng. J. 2019, 358, 1601-1609. [CrossRef]

21. Gao, F.; Cui, W.; Xu, J.P.; Li, C.; Jin, W.H.; Yang, H.L. Lipid accumulation properties of Chlorella vulgaris and Scenedesmus obliquus in membrane photobioreactor (MPBR) fed with secondary effluent from municipal wastewater treatment plant. Renew. Energy 2019, 136, 671-676. [CrossRef]

22. Saeed, Z.; Naveed, M.; Imran, M.; Bashir, M.A.; Sattar, A.; Mustafa, A.; Hussain, A.; Xu, M. Combined use of Enterobacter sp. MN17 and zeolite reverts the adverse effects of cadmium on growth, physiology and antioxidant activity of Brassica napus. PLoS ONE 2019, 14, e0213016. [CrossRef] [PubMed]

23. Naveed, M.; Mustafa, A.; Majeed, S.; Naseem, Z.; Saeed, Q.; Khan, A.; Nawaz, A.; Baig, K.S.; Chen, J.T. Enhancing cadmium tolerance and pea plant health through Enterobacter sp. MN17 inoculation together with biochar and gravel sand. Plants 2020, 9, 530. [CrossRef] [PubMed]

24. Sabir, A.; Naveed, M.; Bashir, M.A.; Hussain, A.; Mustafa, A.; Zahir, Z.A.; Kamran, M.; Ditta, A.; Núñez-Delgado, A.; Saeed, Q.; et al. Cadmium mediated phytotoxic impacts in Brassica napus: Managing growth, physiological and oxidative disturbances through combined use of biochar and Enterobacter sp. MN17. J. Environ. Manag. 2020, 265, 110522. [CrossRef] [PubMed]

25. American Public Health Association. Standard Methods for the Examination of Water and Wastewater, 20th ed.; American Public Health Association/American Water Works Association/Water Environment Federation: Washington, DC, USA, 1998.

26. AOAC. Official Methods of Analyses of the Association of Analytical Chemist, 15th ed.; AOAC: Washington, DC, USA, 1990.

27. Mustafa, A.; Naveed, M.; Saeed, Q.; Ashraf, M.N.; Hussain, A.; Abbas, T.; Kamran, M.; Minggang, X. Application potentials of plant growth promoting rhizobacteria and fungi as an alternative to conventional weed control methods. In Crop Production; IntechOpen: London, UK, 2019.

28. Mustafa, A.; Naveed, M.; Abbas, T.; Saeed, Q.; Hussain, A.; Ashraf, M.N.; Minggang, X. Growth response of wheat and associated weeds to plant antagonistic rhizobacteria and fungi. Ital. J. Agron. 2019, 14, 191-198. [CrossRef]

29. Arkhipova, T.; Galimsyanova, N.; Kuzmina, L.; Vysotskaya, L.; Sidorova, L.; Gabbasova, I.; Melentiev, A.; Kudoyarova, G. Effect of seed bacterization with plant growth-promoting bacteria on wheat productivity and phosphorus mobility in the rhizosphere. Plant Soil Environ. 2019, 65, 313-319. [CrossRef] 
30. Naveed, M.; Mustafa, A.; Azhar, S.Q.T.A.; Kamran, M.; Zahir, Z.A.; Núñez-Delgado, A. Burkholderia phytofirmans PSJN and tree twigs derived biochar together retrieved $\mathrm{Pb}$-induced growth, physiological and biochemical disturbances by minimizing its uptake and translocation in mung bean (Vigna radiata L.). J. Environ. Manag. 2020, 257, 109974. [CrossRef]

31. Gonçalves, A.L.; Pires, J.C.; Simões, M. Wastewater polishing by consortia of chlorella vulgaris and activated sludge native bacteria. J. Clean. Prod. 2016, 133, 348-357. [CrossRef]

32. Hernandez, J.P.; de-Bashan, L.E.; Rodriguez, D.J.; Rodriguez, Y.; Bashan, Y. Growth promotion of the freshwater microalga Chlorella vulgaris by the nitrogen-fixing, plant growth-promoting bacterium Bacillus pumilus from arid zone soils. Eur. J. Soil Biol. 2009, 45, 88-93. [CrossRef]

33. De-Bashan, L.E.; Hernandez, J.P.; Morey, T.; Bashan, Y. Microalgae growth-promoting bacteria as "helpers" for microalgae: A novel approach for removing ammonium and phosphorus from municipal wastewater. Water Res. 2007, 38, 466-474. [CrossRef]

34. Chen, K.C.; Wu, J.Y.; Liou, D.J.; Hwang, S.C.J. Decolorization of the textile dyes by newly isolated bacterial strains. J. Biotechnol. 2003, 101, 57-68. [CrossRef]

35. Chu, W.L.; See, Y.C.; Phang, S.M. Use of immobilised Chlorella vulgaris for the removal of colour from textile dyes. J. Appl. Phycol. 2009, 21, 641-648. [CrossRef]

36. Lim, S.L.; Chu, W.L.; Pang, S.M. Use of Chlorella vulgaris for bioremediation of textile wastewater. Bioresour. Technol. 2010, 101, 7314-7322. [CrossRef]

37. Government of Punjab. Punjab Environmental Quality Standards for Municipal and Liquid Industrial Effluents (PEQS); Government of Punjab: Chandigarh, India, 2016.

38. Yaseen, M.; Aziz, M.Z.; Jafar, A.A.; Naveed, M.; Saleem, M. Use of textile waste water along with liquid NPK fertilizer for production of wheat on saline sodic soils. Int. J. Phytoremediation 2016, 18, 502-508. [CrossRef]

39. Yaseen, M.; Aziz, M.Z.; Komal, A.; Naveed, M. Management of textile wastewater for improving growth and yield of field mustard (Brassica campestris L.). Int. J. Phytoremediation 2017, 19, 798-804. [CrossRef] [PubMed]

40. Travieso, L.; Cañizares, R.O.; Borja, R.; Benítez, F.; Domínguez, A.R.; Dupeyrón, R.; Valiente, V. Heavy metal removal by Microalgae. Bull. Environ. Contam. Toxicol. 1999, 62, 144-151. [CrossRef] [PubMed]

41. Goharshadi, E.K.; Moghaddam, M.B. Adsorption of hexavalent chromium ions from aqueous solution by graphene nanosheets: Kinetic and thermodynamic studies. Int. J. Environ. Sci. Technol. 2015, 12, 2153-2160. [CrossRef]

42. Zhou, G.J.; Ying, G.G.; Liu, S.; Zhou, L.J.; Chen, Z.F.; Peng, F.Q. Simultaneous removal of inorganic and organic compounds in wastewater by freshwater green microalgae. Environ. Sci. Process. Impacts 2014, 16, 2018-2027. [CrossRef]

43. Urrutia, C.; Yanez-Mansilla, E.; Jeison, D. Bioremoval of heavy metals from metal mine tailings water using microalgae biomass. Algal Res. 2019, 43, 101659. [CrossRef]

44. Rinanti, A.; Fachrul, M.F.; Hadisoebroto, R.; Silalahi, M.D. Biosorption of cu (II) by Scenedesmus Obliquus: Optimization in Phovasoli Haemotococcus medium. Int. J. GEOMATE 2018, 15, 45-52. [CrossRef]

45. Pena-Castro, J.M.; Martínez-Jerónimo, F.; Esparza-García, F.; Cañizares-Villanueva, R.O. Heavy metals removal by the microalga Scenedesmus incrassatulus in continuous cultures. Bioresour. Technol. 2004, 94, 219-222. [CrossRef]

46. Chanpiwat, P.; Sthiannopkao, S.; Kim, K.W. Metal content variation in wastewater and biosludge from Bangkok's central wastewater treatment plants. Microchem. J. 2010, 95, 326-332. [CrossRef]

47. Gupta, S.K.; Ansari, F.A.; Shriwastav, A.; Sahoo, N.K.; Rawat, I.; Bux, F. Dual role of Chlorella sorokiniana and Scenedesmus obliquus for comprehensive wastewater treatment and biomass production for bio-fuels. J. Clean. Prod. 2016, 115, 255-264. [CrossRef]

48. Ma, X.; Zhou, W.; Fu, Z.; Cheng, Y.; Min, M.; Liu, Y.; Zhang, Y.; Chen, P.; Ruan, R. Effect of wastewater-borne bacteria on algal growth and nutrients removal in wastewater-based algae cultivation system. Bioresour. Technol. 2014, 167, 8-13. [CrossRef] [PubMed]

49. Cheng, P.; Wang, Y.; Liu, T.; Liu, D. Biofilm Attached Cultivation of Chlorella pyrenoidosa Is a Developed System for Swine Wastewater Treatment and Lipid Production. Front. Plant Sci. 2017, 8, 1594. [CrossRef] [PubMed] 
50. Shahid, A.; Malik, S.; Zhu, H.; Xu, J.; Nawaz, M.Z.; Nawaz, S.; Alam, M.A.; Mehmood, M.A. Cultivating microalgae in wastewater for biomass production, pollutant removal, and atmospheric carbon mitigation; a review. Sci. Total Environ. 2020, 704, 135303. [CrossRef] [PubMed]

51. Zabochnicka-Świątek, M.; Krzywonos, M.; Kalaji, H.M.; El-Sheery, N.I.; Bień, J.B. Influence of clinoptilolite on the efficiency of heavy metal removal from wastewater by C. vulgaris. Desalin. Water Treat 2018, 117, 49-57. [CrossRef]

52. Zabochnicka-Świątek, M.; Kamizela, T.; Kowalczyk, M.; Kalaji, H.M.; Bąba, W. Inexpensive and universal growing media for biomass production of microalgae. Glob. NEST J. 2019, 21, 82-89.

Publisher's Note: MDPI stays neutral with regard to jurisdictional claims in published maps and institutional affiliations.

(C) 2020 by the authors. Licensee MDPI, Basel, Switzerland. This article is an open access article distributed under the terms and conditions of the Creative Commons Attribution (CC BY) license (http://creativecommons.org/licenses/by/4.0/). 